\title{
Cassava By-Products as Feed for Pigs in Burkina Faso: Production Processes, Nutritive Values and Economic Costs
}

\author{
Timbilfou Kiendrébéogo ${ }^{{ }^{*}}$, Nouhoun Zampaligré ${ }^{1}$, Souleymane Ouédraoogo ${ }^{1}$, \\ Youssouf Mopaté Logténé ${ }^{2}$, Chantal Yvette Kaboré-Zoungrana ${ }^{3}$
}

${ }^{1}$ Institut de l'Environnement et de Recherches Agricoles (INERA), Station de Farako-Ba, Bobo-Dioulasso, Burkina Faso

${ }^{2}$ Institut de Recherches en Elevage pour le Développement (IRED), N'Djamena, Chad

${ }^{3}$ Laboratoire d'Etudes des Ressources Naturelles et des Sciences de l'Environnement (LERNSE), Université Nazi Boni,

Bobo-Dioulasso, Burkina Faso

Email: *timbilfou@gmail.com

How to cite this paper: Kiendrébéogo, T., Zampaligré, N., Ouédraoogo, S., Logténé, Y.M. and Kaboré-Zoungrana, C.Y. (2019) Cassava By-Products as Feed for Pigs in Burkina Faso: Production Processes, Nutritive Values and Economic Costs. Open Access Library Journal, 6: e5711.

https://doi.org/10.4236/oalib.1105711

Received: August 16, 2019

Accepted: September 23, 2019

Published: September 26, 2019

Copyright $\odot 2019$ by author(s) and Open Access Library Inc.

This work is licensed under the Creative Commons Attribution International License (CC BY 4.0).

http://creativecommons.org/licenses/by/4.0/

\begin{abstract}
Introduction: In Burkina Faso, as in many countries in sub-Saharan Africa, the low availability and high cost of feed is the main limiting factor for pigs' productivity. While cassava byproducts are well known and used in many countries to overcome this constraint, very little is known on its uses as feed in Burkina Faso. Objective: The study aims to develop processes for the production of pig feeds from cassava leaves and by products (peelings and residues of sieving for gari making). Experimentations: Some cassava leaves, peelings and residues of sieving gari were collected, sun-dried and milled (peels and residues) or mortared (leaves). The dry matter contents were 88.89\%, 90.83\% and $91.67 \%$ respectively for food of cassava peeling (FCP), leaves (FCL), and gari sieving residues (GRSF). The crud protein (CP) contents were $28.87 \%$ for FCL, $4.22 \%$ for FCP and $1.72 \%$ for GRSF. Crude fiber (CB) and ADF were $15.98 \%$ and $30.6 \%$ for FCP, $15.79 \%$ and $23.29 \%$ for FCL and $3.27 \%$ and $4.45 \%$ for GRSF. The NDF content of FCL $(45.32 \%)$ was higher than the FCP (38.36\%) and GRSF (18.42\%) feed respectively. Lignin levels were more important in FCP than in FCL and GRSF. The digestible energy (DE) contents were $2424 \mathrm{kcal}$ for FCL, $2683 \mathrm{kcal}$ for FCP and 3471 kcal DE for GRSF. The production costs of a kg of Dry Matter (DM) of FCP were 15 FCFA, FCL were 101 FCFA and 150 FCFA for GRSF. Conclusion: Pig's feed production based on cassava by-products in Burkina Faso is a good opportunity to make feed more available at reduced cost. Further research is needed to assess pigs zootechnical performances and cost benefits of pig's diets with these feeds.
\end{abstract}




\section{Subject Areas}

Agricultural Science, Animal Behavior

\section{Keywords}

Cassava By-Products, Animal Feed Technologies, Pigs Feed, Burkina Faso

\section{Introduction}

In many countries in sub-Saharan Africa (SSA), pig farming is still widely practiced on an extensive production system. However, pig and poultry farms are expected to play an important role in the rapid increase of animal proteins, given their high productivity potential [1]. The improvement of livestock systems ensures a profitability that is variably appreciated, and above all depends on the availability and cost of feed on all production factors [2]. Feed is a key factor in the development of pig farming in SSA. Feed cost represents the highest share of the cost of pig production [3]. It is estimated about $60 \%$ to $70 \%$ of production costs [2] [3]. Thus, feed, seen in terms of the low availability and high cost [4] [5] and lack of technical knowledge on appropriate feeding in a balanced ration [1], is the main constraint for the development of pig farming in many African countries. In Burkina Faso, there was a significant numerical increase of $18.6 \%$ per year in the number of pigs [6] between 1993 and 2003. The pig herd is estimated at 2,489,317 heads in 2017 according an official growth rate of $1.9 \%$ per year [7]. Like other SSA countries, several studies indicate that feed constraints limit the development of pig farming, or even its intensification in Burkina Faso [5] [8] and [9]. To reduce the impact of feeding constraints, research towards balanced rationing applied to different livestock systems in West Central Burkina Faso [8] and the use of non-conventional feed resources such as mango waste [6] [10] has been conducted to make feed and feed formulas for pigs more available and at lower cost for farmers. This approach aimed at reducing the high cost of feed ingredients in the so-called emerging economies. This reduction in the high cost of feed ingredients consists in using alternative ingredients, including agricultural and agro-industrial waste, as in the case of cassava. The use of cassava and its by-products in livestock feed is a known practice in tropical countries [11] [12]. In Ghana, $47.8 \%$ of livestock farmers in the coastal zone reported using cassava peels as a food source for goats [13]. Cassava peel meal could be included in the feed of growing pigs by up to $30 \%$ to reduce feeding costs without affecting yield, or up to $60 \%$ (total replacement of maize) when maize costs are high [13]. The tuber root of cassava is mainly a source of carbohydrates and can completely replace maize as an energy source in pig and poultry feed [12] [13] and [14] showed that the incorporation of $40 \%$ and $60 \%$ of fermented cassava peelings into broiler diets was possible and contributed to reducing diet costs by $27.3 \%$ and $23.9 \%$ respectively. Despite the importance of cassava by-products as alternative 
sources of feed for pigs in many countries in SSA, very little information on their use as pig feed is available for Burkina Faso. The objective of the study was to develop simple feed production processes based on cassava production and processing by-products that could be used in the feeding of farm animals, particularly pigs.

\section{Material and Methods}

\subsection{Study Area and Cassava Production Potential}

Description of the study area: The study took place in the town of Gaoua, in southern Burkina Faso, a city of 52,733 inhabitants in 2006, during the last general census of the population of Burkina Faso [15]. The climate is Soudanian with rainfall ranging between 900 and $1200 \mathrm{~mm}$. The region has two main seasons, one wet season from April to October (7 months) and one dry season from November to March ( 5 months). The dry season is characterized by Harmattan with a dry and cool wind from November to February and temperatures ranging from $21^{\circ} \mathrm{C}$ to $32^{\circ} \mathrm{C}$. Pig farming is practiced there, with an estimated herd of 251,176 heads, or $13.5 \%$ of Burkina Faso's pig population.

Cassava production potential: Cassava production in Gaoua is expanding with planted areas increasing from 47 ha in 2011/2012 to 71.5 ha in 2012/2013. Tuber production increased from $1104.5 \mathrm{t}$ in 2011/2012 to $1680.25 \mathrm{t}$ in 2012/2013. The main product of manioc processing in Gaoua is the cooked gari called attieke in a local language, in Ivory Coast. Nearly 180 processing units have been identified in the province of Poni, five (5) are semi-automated, two (2) of which are based in the city of Gaoua. The processing yield being $49 \%$, we could obtain 241.20 tons of peelings, 9.57 tons in raw flour sieving residues from attieke if we processed the entire Gaoua production [16]. To these processing residues, 107.25 tons of dry leaves can be added (in 2 cuts). Apart from the sieving residues, peelings and leaves have hitherto been given very little value in the feed. However, the unavailability of feed (highlighted by $89 \%$ of pig farmers) and its high cost (65\%) are the main constraints of pig farming in Gaoua. However, with a crude protein content of $25 \%$ in cassava leaves, the crude protein potential in Gaoua department would be 27 tons, which would be sufficient to cover the protein needs of 530 pigs for one year.

\subsection{Feed Production Processes Based on Cassava Waste}

The sun drying method has been chosen to obtain dry feeds with a moisture content of less than $14 \%$, which facilitates their storage and transport [17]. The treatment of cassava waste by drying and milling it into flour not only facilitates its incorporation into the ration but also significantly reduces cyanide (HNC) levels 1 [8]. This substance and tannins are toxic in Non-ruminant animals.

- Food of cassava leaves (FCL): Leaves were harvested either from cassava plants in production or from the stems after the tubers were harvested. The harvested leaves are spread on tarpaulins to be dried in the sun. After drying, 
they are crushed in a mortar and the coarse powder obtained is sieved with a 1 - 2 mm mesh sieve.

- Food of cassava peelings (FCP): The peels are derived from the stripping of tubers with a knife in the process of processing cassava in gari and attieke. These previously discarded peels are bought back from processors. They are spread on tarpaulins and dried in the sun. Once dry, they are ground in the mill to obtain the cassava peel feed (FCP).

- Gari residues sieving food (GRSF): The gari's sieve residues are obtained in the last phase of processing the tuber into gari. The raw flour of the soaked and dried cassava is sieved to obtain finer flour. The parts that do not pass through the sieve are the residues of the gari sieving. These residues are recovered, dried in the sun and crushed at the mill to obtain flour from residues from the sieving of gari raw flour (GRSF).

\subsection{Assessment of the Nutritional and Energy Inputs of Raw Materials Harvested for Process Development}

\subsubsection{Determination of the Chemical Composition of Cassava Byproduct Foods}

During the harvest of the leaves in the field and the collection of fresh peelings of tubers, samples of leaves, leaves + stalks and fresh peelings were collected and sent to the chemistry laboratory of the Burkina Faso Bureau of Mines and Geology (BUMIGEB) based in Bobo-Dioulasso for the determination of HCN contents. Once dried in the sun and ground into powder, samples were taken from FCP, FCL and GRSF feeds and sent to the Senegalese Agricultural Research Institute's chemistry laboratory in Dakar to determine their chemical composition. The determinants concerned the percent levels of MS, MAT, CB, Ca, P, NDF and ADF, ADL, MG and Inch. Proximate chemical contents (DM, CP, CB, Ca, P, Asj, ADF, NDF, NaCl) were determined using methods of AOAC (1975) [10].

\subsubsection{Determination of the Energy Value of Cassava Byproduct Foods}

The contents of Gross Energy (GE) and Digestible Energy (DE) in feed of FCL), (FCP) and GRSF were calculated by applying [18] energy prediction equations:

$$
\begin{aligned}
& \mathrm{EB}=5.74 \mathrm{MAT}+9.50 \mathrm{MG}+4.79 \mathrm{CB}+4.17 \mathrm{ENA} \pm 0.9 \% \text { with } \\
& \mathrm{EB}=\text { Gross energy; } \\
& \mathrm{MAT} \text { = Total nitrogenous matter; } \\
& \mathrm{MG}=\text { Fat content; } \\
& \mathrm{CB}=\text { Crude fibre; } \\
& \mathrm{ENA}=\text { Non-nitrogenous extract; } \\
& \mathrm{DE}(\mathrm{kcal} / \mathrm{KgMS})=\mathrm{EBxdE} / 100 \text { with } \mathrm{dE}=\text { energy digestibility with } \\
& \mathrm{dE}=96.36-0.872 \mathrm{NDF},(\mathrm{R}=-0.947) .
\end{aligned}
$$

\section{Results}

\subsection{Production Process of the Cassava Peel Feed (FCP)}

The cassava peelings were harvested (Figure 1(a)) and damages leaves elimi- 
nated to avoid contamination. In these peelings whole some tubers were found also. These tubers have been cut into chips to facilitate their drying in the sun (Figure 1(b)). The peelings were then spread on plastic sheeting and exposed to the sun (Figure $1(\mathrm{c})$ ). In the dry state after 3 - 4 days of drying, the peelings were milled. This provides the cassava peel (FCP) feed (Figure 1(d)).

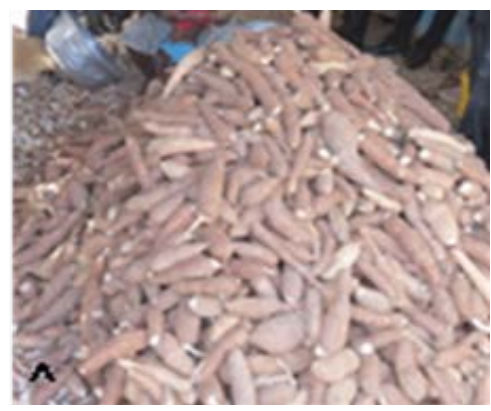

(a)

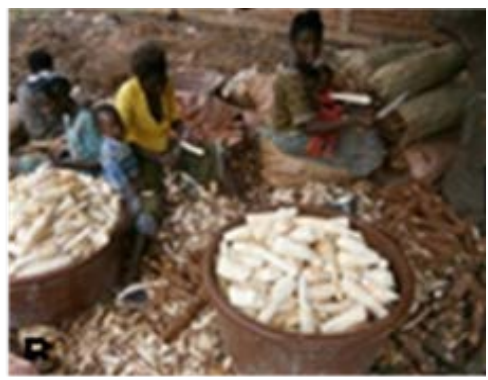

(b)

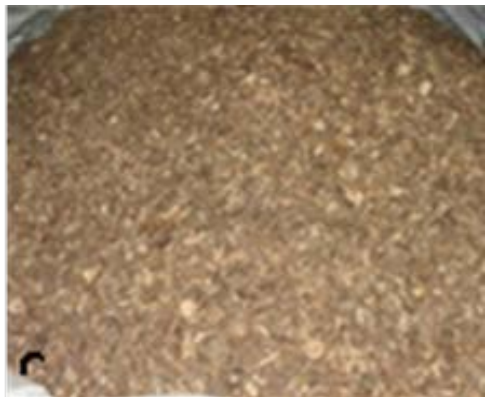

(c)

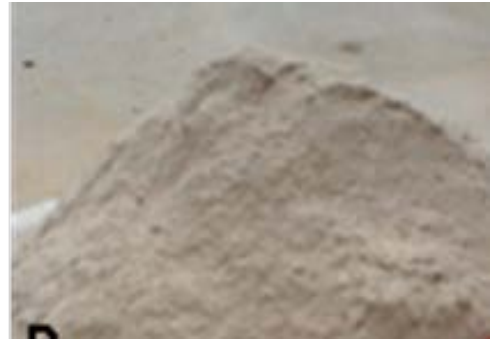

(d)

Figure 1. Production process of cassava peel. (a) Fresh cassava tubers in an Attieke production Unit in Gaoua; (b) Fresh peelings of cassava tubers in an Attieke production Unit at Gaoua; (c) Sun-dried cassava tuberpeelings; (d) Cassava peel food (CPF): cassava skin flour obtained after grinding the sun-dried cassava peels in a mill. 


\subsection{Production Process of Gari Raw Meal Sieving Food (GRSF)}

In processing of cassava into gari, the peeled tubers are crushed fresh and put in bags for a few days for fermentation. This paw is then pressed to be dehydrated physically. The paw after dehydration is sieved, which gives gari for the part that has passed through the mesh of the sieve and the sieving residue for the other part remained downstream. This last part, calling sieve residue of gari (GSRF), is recovered (Figure 2(a)) and sun-dried on bags (at the transformers) or on a tarpaulin in our case (Figure 2(b)). In the dry state after 2 - 3 days of drying the GSRF were grinded at the mill, to obtain the GRSF (Figure 2(c)).

\subsection{Production Process of Cassava Leaf Feed}

The cassava leaves are harvested in the field either directly on the plant or recovered after harvesting the tubers (Figure 3(a)). The harvested leaves were then

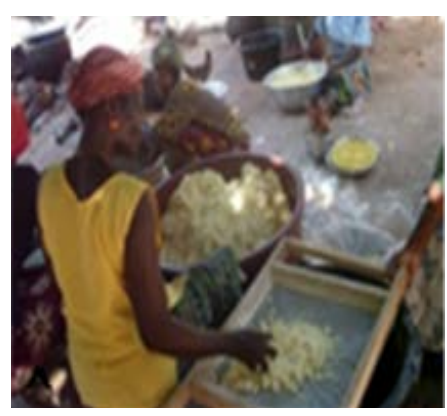

(a)

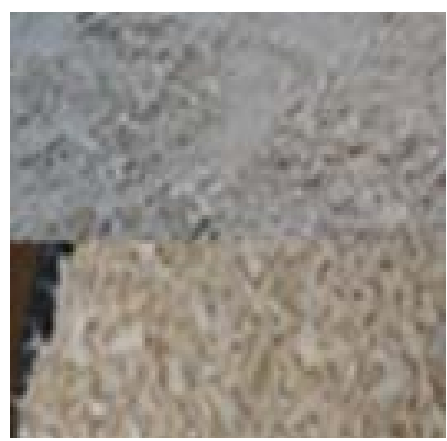

(b)

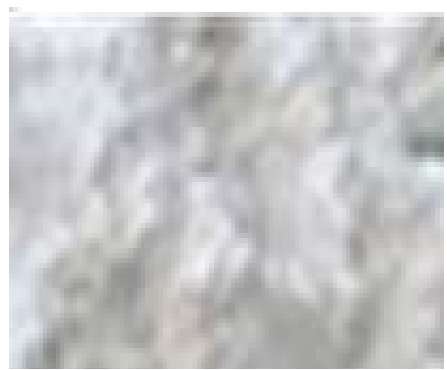

(c)

Figure 2. Production process of gari sieving residue flour. (a) Gari sieving in the process of production of attieke; (b) Residue of dried sieving of gari in a productionunit of attieke in Gaoua; (c) Fresh peelings of cassava tubers in an Attieke production Unit at Gaoua. 


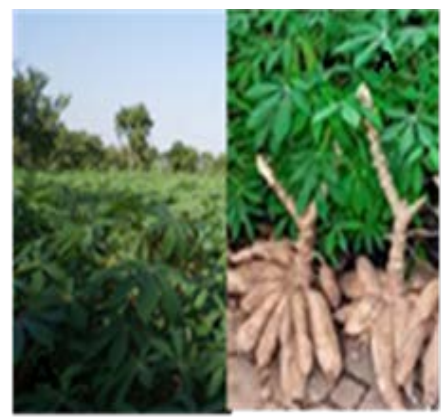

(a)

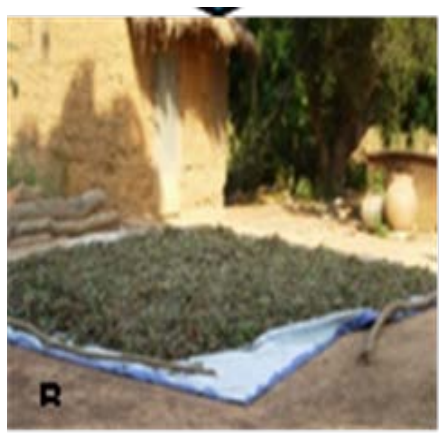

(b)

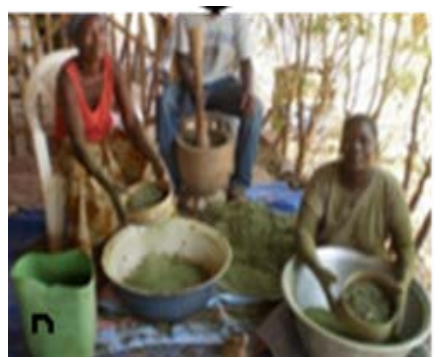

(c)

Figure 3. Process of producing cassava leaf meal. (a) Field and cassava harvest from where theleaves are obtained; (b) Cassava leaves drying in the sun on a tarpaulin in Gaoua; (c) Grinding of dried manioc leaves with mortar.

spread hard on the tarpaulin to be dried in the sun (Figure 3(b)). The sun-dried leaves were crushed with mortar and sieved (Figure 3(c)) to obtain the food cassava leaves (FCL). A new market for peelings and sieving residues of raw gari flour has been created thanks to the proven ability to use them to feed pigs. A pig farmer was convinced and committed to the creation of a feed production unit incorporating cassava by-products.

\subsection{Feed Values and Production Costs of Cassava Byproduct Feed}

The proximate chemical composition and energy content of the incorporated portions of cassava (Table 1) show that the total nitrogen contents of the FCP and GRSF feeds were very low. FCL and FCP feeds have higher fiber contents (CB, ADF, NDF) than GRSF. The ED content of GRSF was higher than that of MEAs and FCLs. Production costs per kilogram of FCP, FCL and GRSF food 
were CFAF 15, CFAF 101 and CFAF 150 respectively. Only fresh leaves and stems taken together contained hydrocyanic acid at $0.04 \mathrm{ppm}$. The results of estimate potential amino acid contribution in FCL represent 7.5 times the contribution of FCP and 2.18 times the GRSF one. This contribution in money equivalent is in the same magnitude (Table 2)

Table 1. Nutrient $(\mathrm{kg})$ and energy (kcal) supply of feed produced from the quantities of raw materials harvested for process development.

\begin{tabular}{cccc}
\hline \multirow{2}{*}{ Food parameters } & \multicolumn{3}{c}{ Aliments } \\
\cline { 2 - 4 } Dry matter & 330 & FCL & GRSF \\
\hline Total nitrogenous matter & 16 & 382 & 2897 \\
Minerals & 30 & 120 & 55 \\
Calcium & 0.74 & 35 & 42 \\
Phosphorus & 1.00 & 1.42 & 3.19 \\
Fat & 12 & 2.25 & 3.83 \\
Crude fibre & 59 & 20 & 35 \\
NDF & 142 & 66 & 104 \\
ADF & 113 & 189 & 588 \\
Insoluble chloridic & 13 & 97 & 142 \\
Lignin & 54 & 5 & 73 \\
Gross energy & $1,586,386$ & $1,787,999$ & $13,774,420$ \\
Digestible energy & 994,921 & $1,011,225$ & $11,072,490$ \\
Cost (FCFA) & 14,924 & 42,134 & 478,500 \\
\hline
\end{tabular}

FCP $=$ Food of Cassava peel; FCL $=$ Food of Cassava leaves; GRSF $=$ Gari residues sieving food.

Table 2. Intakes of a few essential amino acids and costs of lysine and methionine at the selling price in Bobo-Dioulasso.

\begin{tabular}{ccccc}
\hline \multirow{2}{*}{ Nutrients Parameters } & & \multicolumn{3}{c}{ Feed } \\
\cline { 3 - 5 } & & FCP & FCL & GRSF \\
\hline \multirow{2}{*}{ Lysine $^{*}$} & Weight (g) & 944 & 7080 & 3245 \\
& Cost (FCFA) & 2643 & 19,824 & 9086 \\
Methionine & Weight (g) & 272 & 2040 & 935 \\
Cystine & Cost (FCFA) & 1360 & 10,200 & 4675 \\
Tryptophan & Weight (g) & 192 & 1440 & 660 \\
Arginine $^{* *}$ & Weight (g) & 320 & 2400 & 1100 \\
\hline
\end{tabular}

FCP $=$ Food of Cassava peel; FCL $=$ Food of Cassava leaves; GRSF = Gari residues sieving Food. ${ }^{\star}$ Amino acids commonly used on sale at the provendierson the local market; ${ }^{* *}$ Amino acids not available and not sold in pure synthesis, necessary in the rationing of pigs and reported in some concentrates sold on the local market. 


\section{Discussion}

\subsection{Procedures for Treating Leaves and Cassava Residues and Their Incorporation into Diets}

The study has developed processes for the production of feed based on cassava production and processing waste that can be used as pig feed. The process by sun drying feed reduced water contents and allowed good conservation of the obtained feed. In fact, the water content of the three (3) feeds obtained (FCP, FCL, GRSF) had dryness levels of $3-5$ points at $14 \%$, a rate above which the stability of products in conservation is no longer assured according to [16]. Compared with dry matter levels of fresh cassava peels (27.3\%) and fresh peeled tubers (comparable to GRSF) (30.8\%) reported by [19], substantial grade improvement in DM of $255 \%$ for FCP and $195 \%$ for GRSF was observed by the application of production processes by sun drying. This improvement is essential in feed and animal nutrition because the DM is the stable base on which all the rationing calculation are made. Drying facilitates the conservation of cassava without necessarily modifying the chemical composition. In fact, the chemical composition of whole cassava and dried chips, put in boxes and stored in hermetic silos, was comparable to that of fresh tubers [20]. The practice of drying becomes mandatory in its use to feed non ruminants [21]. In addition, fresh feeds have a high temporal variability in their composition which is not a guarantee of the constancy of nutritional supply levels. This requires periodic readjustments. In addition, high moisture levels are responsible for rapid degradation of feed [22]. At the processing unit level, the management of fresh cassava peel was a real problem in Gaoua, before our experimentation. Indeed, the promoters were obliged to make additional expenses for the removal of the peelings and their discharge in order to avoid the nuisance to the residents following their decomposition.

Our results show that the CP contents of FCP and GRSF feeds are lower than those of cassava leaves. Our results for the same feeds are very similar to those reported by [22] compared to peeled fresh tubers (68.2\% water). These results were $4.22 \%$ vs. $5.2 \%$ for FCP and $1.62 \%$ vs. $2.1 \%$ for GRSF. They are much lower than the results reported by [4] for breweries residues (23.26\%) and traditional beer curd (18.55\%). On the other hand, cassava leaf feed (FCL) was 5 times higher than that of FCP, 16 times that of GRSF and 3 times that of alcohol residues and 01 times that of bear bean reported by the same author. One of the components to monitor is hydrogen cyanide ( $\mathrm{HCN}$ ), which is a toxic element for non-ruminants. Analysis of fresh samples of leaves, peelings, raw gari flour sieving residues and cassava stem leaves revealed the presence of HCN only in the leaf + stem sample. This content $(0.04 \mathrm{~g} / \mathrm{kg} \mathrm{DM})$ was much less than 6 times the lowest grade $(0.29 \mathrm{~g} / \mathrm{kg} \mathrm{DM})$ found for a variety called Gon and 12 times that of another variety called KM94 (0, $51 \mathrm{~g} / \mathrm{kg} \mathrm{MS})$ reported by [19]. The absence of $\mathrm{HCN}$ in the samples of the raw materials used for the process and the very low content in the stems + leaf sample, moreover desired, is certainly due to the in- 
troduction of so-called improved varieties with high yields and low HCN concentration in the Gaoua area. We are more assured of the absence or the presence but trace HCN because of the effect of drying. The results reported by [19] show that in just 2 days of simple leaf-drying, about $90 \%$ of the HCN content was reduced, as opposed to post-silage drying which could only reduce the rates by $60 \%$. The FCL MAT content was higher than that reported by [20] for cassava leaves $(28.87 \%$ vs. $20.10 \%)$; and on the other hand, closer to MAT contents of $27.5 \%, 27.6 \%$ and $26 \%$ reported by [19] for ensiled cassava leaves then dried in the sun. This indicates that in conditions of good sunshine silage work in time and cost can be reduced only dehydrating in the sun. The good level of CP in the leaves may well complement the deficiency observed in peelings and gari sieving residue in the ration formulation for pigs. As with the DM, the processes allowed a higher concentration of the MAT contents in the dry flours than in the fresh materials. Fiber contents, in particular ADF, are approximately 2 times higher than that of breweries Residue and 0.5 times higher than that of Ditch reported by [4]. The gap widens further with the ADF, which is 7 and 1 times higher than the reported rates for alcohol residue and spent grain. The NDF levels of FCP and FCL of feeds are close to those reported by [10] for sun dried mangoes waste. ADF of (FCP, 30.6\%) and (GRSF, 23.9\%) are of 0.1 and 0.5 times higher than the contents of the mangoes' feed reported by the same authors. The levels of lignin that are completely indigestible are 3 and 2 times more important for FCP and FCL feeds, respectively than those of mango feeds reported by [10]. The NDF content of GRSF is much lower than those reported by [10] for mango feeds and higher compared to Residues of Native Alcohol and Traditional Beer Drags [4]. The Crude fiber content of this last feed is very similar to that reported by [22] for fresh tubers (3.27\% vs. $2.8 \%)$ and fresh peeled tubers $(3.27 \%$ vs. $1.5 \%$ ), but 3 times less than those of fresh cassava peels (31.50\% moisture) reported by the same authors. The crude cellulose (CC) content for FCP and GRSF of around $16 \%$ for each is 7 points higher than for mangoes. One of the characteristics of both FCP and FCL feeds is their more fibrous nature than the GRSF food. This explains the lower DE content of the two feeds compared to the GRSF food, while the Gross Energy (GE) is almost equal for the three feeds. For the production of lean pork that is preferred by African consumers, these feeds are more suitable [4] [5]. Experiments with the use of mango feeds produced under almost the same conditions and with high fiber content enabled the production of lean pigs.

\subsection{Economic Performance of Processes}

The production costs of cassava leaves meal and peel feeds and the purchase price of raw gari flour sieving residues indicate that the feed is competitive with some locally available feeds. These costs and prices in the range of CFAF 15 to $150 / \mathrm{kg}$ of feed are lower than the prices of corn bran (CFAF 142.86) and corn kernels (CFAF 250) sold in the market of Bobo-Dioulasso in 2014, as well as the 
production cost of feed made with mango + skin pulp (PPS) reported by [10] estimated at 147.25 FCFA. The production cost of cassava peel flour was equivalent to mango skin + provender (PMS) (101 FCFA) reported by the same authors. The production cost per kilogram of leaves meal is close to the selling price of dry dolphins, which averaged 17 F CFA/kg in Bobo-Dioulasso in 2011. The results on the evaluation of nutrient and ED inputs by harvested raw materials show that the processes make it possible to produce simple and cheaper feeds based on cassava production and processing waste. Indeed, it would have been necessary to spend 9 times, 3 times and 2 times more than the feed production expenses from raw materials harvested, to acquire Soybean cake which would offer the equivalent in feed ED. It is important to note the other dietary intakes that we have not analyzed but evaluated in Table 2. The amino acids found there are of great importance as catalysts for the efficient use of nutrients. These amino acids are generally imported from Europe in most African countries and sold by the provendiers. By this way, they increase the cost of rations. The production of simple feeds based on cassava waste appears as an alternative way to supplement these amino acid requirements while reducing acquisition costs. The development of processes for the purchase of peelings and sieving residues of raw gari flour has created an additional market for sieving residues of gari flour and a new market for peelings. Instead of spending money to transport peelings out of the unit and away from residents to avoid nuisance, peelings were now sold to farmers in their order of demand. The subsequent introduction of diet-based swine feeding trials incorporating FCP, FCL and ERTG feeds into pig farms in Gaoua has been a means of informing and raising the awareness of pig farmers that by-products of cassava production and processing could be used in pig feed. This has prompted many of them to buy peelings and sieving residues of raw gari flour at processing units. One of the breeders participating in the trial has taken steps to set up a feed mill that would exploit the by-products of cassava.

\section{Conclusion}

Our results show the potential for upgrading cassava crop and processing residues through the processes developed. The feeds obtained have good levels in various nutrients and energies. Cassava leaves are particularly rich in protein and can therefore compensate the deficiency observed in peeled food (MEA) and sieved residues of raw gari flour (GRSF). Apart from the GRSF feed, the fiber contents are high for the other two feeds. However, they can be used in rations for the production of lean pigs. The processes are simple and replicable by actors, farmers and breeders and allow the recovery of large quantities of cassava waste that had been discarded or abandoned in the fields in Burkina Faso. These feeds can be used alone or go into the composition of diets. They will replace maize and other cereals in non-ruminant diets, especially pigs, where energy is predominant in production. The process of processing peelings, leaves and the 
purchase of the residue had the first effect, to provide information to cassava processors in gari and attieke and to breeders that it was possible for the first to sell the waste. And the latter to use cassava and cassava leaves as well as its processing waste to feed animals, especially pigs. The uses of cassava waste allowed to make simple and low-cost feeds available for pig breeding. It creates added value for processors while contributing to the improvement of their living and working environment. Work on the use of feed produced by these processes will be required to evaluate their efficiencies on pig and farm productivity. Future analyses to determine essential amino acid content and anti-nutritional substances such as tannins that play an important role in the valuation of non-ruminant diets will be necessary.

\section{Conflicts of Interest}

The authors declare no conflicts of interest regarding the publication of this paper.

\section{References}

[1] Ndébi, G., Kamajou, J. and Ongla, J. (2009) Analyse des contraintes au développement de la production porcine au Cameroun. Tropicultura, 27, 70-76.

[2] Tra Bi Tra, C. (2009) Filière porcine en Côte d'ivoire: Production, Propositions d'amélioration et perspectives de développement. Université Cheik Anta Diop de Dakar, Ecole Inter-Etats des Sciences et Médecine Vétérinaire (E.I.S.M.V.), Dakar Sénégal, 96 p.

[3] Letournereau Montmini, M.-P., Boucher, C., Pomar, C., Dubeau, F. and Dusault, J.P. (2005) Impact de la méthode de formulation et du nombre de phases d'alimentation sur le coût d'alimentation et les rejets d'azote et de phosphore chez le porc charcutier. Journées Recherche Porcine, 37, 25-32.

[4] Mopaté, L.Y., Kaboré-Zoungrana, C.Y. and Facho, B. (2011) Disponibilités et valeurs alimentaires des drêches artisanales et résidus d'alcool traditionnel mobilisables dans l'alimentation des porcs dans la zone de N'Djaména (Tchad). Journal of Applied Biosciences, 42, 2859-2866.

[5] Kiendrébéogo, T., Mopaté, L.Y. and Kaboré-Zoungrana, C.-Y. (2014) The Typology of the Pig Breeding in Burkina Faso: Cases of the Towns of Bobo-Dioulasso and Gaoua in Soudanian Area; Kaya and Dori in Sahelian Area. International Journal of Agronomy and Agricultural Research, 4, 119-136.

[6] Kiendrebeogo, T., Mopate, L.Y. and Kabore-Zoungrana, C.-Y. (2018) Effets de rations à base de déchets de mangue sur les performances pondérales et la qualité de la carcasse de porcs Korhogo en croissance au Burkina Faso. Journal of Applied Biosciences, 129, 13039-13049. https://doi.org/10.4314/jab.v129i1.7

[7] FAOSTAT (2019) Données statistiques de l'Organisation des Nations Unies pour l'alimentation et l'agriculture. http://www.fao.org/faostat/fr/\#data

[8] Bosma, R.H., Zongo, L.C., Sané, A., Zoungrana, C. and Soudré, A. (2004) Comparaison participatoire de trois méthodes d'engraissement des porcs dans les provinces du Sanguié et du Boulkiemdé au Burkina Faso. Livestock Research for Rural Development, 16, 1-9. http://www.lrrd.org/lrrd16/2/bosm1602.htm

[9] Bougouma-Yamoégo, V.M.C., Ouédraogo, C.L., Wereme-Ndiaye, A. and Konkobo, 
B. (2005) Influence du niveau énergétique sur les performances de croissance et d'engraissement bouchères du porc local: Valeur bouchère et rentabilité économique des rations. Revue Africaine pour la Santé et la Production Animale, 3, 205-211.

[10] Kiendrebeogo, T., Mopate, L.Y. and Kaboré-Zoungrana, C.-Y. (2013) Procédé de production d'aliments non conventionnels pour porcs à base de déchets de mangues et détermination de leurs valeurs alimentaires au Burkina Faso. Journal of Applied Biosciences, 67, 5261-5270. https://doi.org/10.4314/jab.v67i0.95047

[11] Olurin, K.B., Olojo, E.A.A. and Olukoya, O.A. (2006) Growth of African Catfish Clarias gariepinus Fingerlings, Fed Different Levels of Cassava. International Digital Organization for Scientific Information, 1, 54-56. http://www.idosi.org/wjz/wjz1(1)2006/8.pdf

[12] Tewe, O. and Egbunike, G.N. (1988) Utilization of Cassava in Nonruminant Livestock Feeds. In: Cassava as Livestock Feed in Africa: Proceedings of the IITA/ILCA/University of Ibadan Workshop on the Potential Utilization of Cassava as Livestock Feed in Africa, Ibadan, Nigeria, 14-18 November 1988, 38 p.

https://betuco.be/manioc/Cassava\%20-\%20as\%20livestock\%20feed\%20in\%20Africa \%20FAO.pdf

[13] Kwame, O.-A. (2013) Cassava as Animal Feed in Ghana: Past, Present and Future. Food and Agriculture Organization of the United Nations Accra, Rome, Italy. http://www.fao.org/docrep/018/i3304e/i3304e.pdf

[14] Aro, S.O., Agbede, J.O., Dairo, O.O., Ogunsote, E. and Aletor, V.A. (2012) Evaluation of Fermented Cassava Tuber Wastes in Broiler Chickens Feeding. Archiva Zootechnica, 15, 49-60.

[15] MEF (Ministère de l'Economie et des Finances) (2009) Recensement général de la population et de l'habitat de 2006 (RGPH-2006), monographie de la région du Susd-Ouest, $152 \mathrm{p}$.

[16] MHRH et CAD (2008) PDA (Programme de Développement de l'Agriculture), diagnostic actualisé de la filière manioc pour une analyse de chaines de valeur ajoutée (CVA). 26 p.

[17] Arnoldus, M. and Floris, V.P. (2009) L'amélioration de la performance des produits transformés de la mangue au Burkina Faso et au Mali. Rapport d'étude. Royal Tropical Institute, $116 \mathrm{p}$.

http://www.globalfacts.nl/documents/FINALREPORTWorldBankRapportMangue. pdf

[18] Ravindran, V. (1993) Cassava Leaves as Animal Feed: Potential and Limitations. Journal of the Science of Food and Agriculture, 61, 141-150. https://www.researchgate.net/profile/Velmurugu_Ravindran/publication/22952813 0_Cassava_leaves_as_Animal_Feed_Potential_and_Limitations/links/5a3186ac4585 15afb6687d48/Cassava-leaves-as-Animal-Feed-Potential-and-Limitations.pdf https://doi.org/10.1002/jsfa.2740610202

[19] Gómez, G. and Valdivieso, M. (1988) The Effects of Ensiling Cassava Whole-Roots Chips on Cyanide Elimination. Nutrition Reports International, 37, 1161-1166. http://www.sidalc.net/cgi-bin/wxis.exe/?IsisScript=catalco.xis\&method=post\&form ato $=2 \&$ cantidad $=1 \&$ expresion $=\mathrm{mfn}=045427$

[20] Henry, Y. (1971) Essai de prévision de la valeur en énergie digestible des aliments pour le porc àpartir de leur teneur en constituants membranaires.

https://www.google.com/search?sxsrf=ACYBGNSD_LX_h-cPhrSodSuS_4nJKIWY8 w\%3A1568231107551\&ei=w055XdesIfeS1fAPg8q8mA0\&q=+http\%3A\%2F\%2Fjour nees-rechercheporcine.com\%2Ftexte\%2F1971\%2F71txtAlim\%2FA7102.pdf\&oq=+h 
ttp\%3A\%2F\%2Fjournees-rechercheporcine.com\%2Ftexte\%2F1971\%2F71txtAlim\% 2FA7102.pdf\&gs_l=psy-ab.12...12558.12558..16079...0.0..0.369.369.3-1.....0....1..gwswiz.wBHr-U6DJzQ\&ved=0ahUKEwiXmt2QxMnkAhV3SRUIHQMlD9MQ4dUDC Ao

[21] Bindelle, J. and Buldgen, A. (2004) Utilisation des plantes à tubercules ou à racines tubéreuses en alimentation animale. Troupeaux et Cultures des Tropiques, 4, 47-50. https://orbi.uliege.be/bitstream/2268/20764/1/article\%20sous-produits.pdf

[22] Phuc, B.H.N., Ogle, B. and Lindberg, J.E. (2000) Effect of Replacing Soybean Protein with Cassava Leaf Protein in Cassava Root Meal-Based Diets for Growing Pigs on Digestibility and N Retention. Animal Feed Science and Technology, 83, 223-235. https://pdfs.semanticscholar.org/fcb6/5ad670101499a3344144880a4486b2009ff5.pdf https://doi.org/10.1016/S0377-8401(99)00136-4 